\title{
Góra Zelce jako walor geoturystyczny Wyżyny Woźnicko-Wieluńskiej z uwzględnieniem analizy geomorfologicznej
}

\section{Zelce Mountain as a geotouristic value of the Woźniki-Wieluń Upland, including geomorphological analysis}

\begin{abstract}
Zarys treści
Góra Zelce na Wyżynie Wieluńskiej od 1971 roku objęta jest ochroną rezerwatową dotyczącą form krasowych ostańca jurajskiego. $Z$ reguły ochroną obejmowane są formy naturalne, mało przekształcone przez człowieka. W przypadku Góry Zelce i Rezerwatu „Węże” mamy do czynienia z obiektem silnie przekształconym antropogenicznie. Przekształcenia te wynikały z wieloletniej eksploatacji kalcytu dla potrzeb przemysłu hutniczego. Pozostały po tym liczne wyrobiska i hałdy oraz korytarze jaskiń w większości pozbawione szaty naciekowej. Przez większość okresu funkcjonowania rezerwatu obiekty jaskiniowe były dostępne dla powszechnego ruchu turystycznego. W ostatnich latach, ze względów ochrony środowiska, dostęp do jaskiń został zamknięty. W artykule przedstawiono rezultaty badań na temat przekształcenia rzeźby oraz stanu jaskiń. Autorzy wskazują na możliwość ograniczenia ochrony rezerwatowej na badanym obszarze.
\end{abstract}

Słowa kluczowe Góra Zelce, Rezerwat „Węże”, ostańce jurajskie, jaskinie krasowe, przekształcenia antropogeniczne.

Abstract

Zelce Mountain in the Wielun Upland has been protected since 1971 by reserve protection regarding karst forms of the Jurassic Mound. As a rule of thumb, protection is granted to natural forms, little transformed by human activity. In the case of Góra Zelce and the "Węże" nature reserve, we are dealing with a strongly anthropogenic transformation. These transformations resulted from many years of calcite exploitation for the needs of the steel industry. Numerous excavations and heaps remained, as well as cave corridors, mostly devoid of dripstone formations. For most of the period of operation of the reserve, cave facilities were available to the general tourist traffic. In recent years, access to caves has been closed for environmental reasons. The article presents the results of research on the transformation of the relief and the condition of the caves. The authors point to the possibility of limiting the reserve protection in the studied area.

Keywords

Zelce Mountain, "Węże" Reserve, Jurassic monadnocks, karst caves, anthropogenic transformations.

\section{Wprowadzenie}

Badany obszar położony jest na północnym krańcu Wyżyn Polskich (ryc. 1A) i oprócz góry Świętej Genowefy stanowi on jedno z ostatnich miejsc, gdzie lite skały jurajskie w naturalny sposób tworzą wyraziste wychodnie na powierzchni terenu (Szmidt 2006). Według regionalizacji fizycznogeograficznej Solona i in. (2018) obszar badań położony jest (ryc. 1B) w prowincji Wyżyny Polskie (34), podprowincji Wyżyna Śląsko-Krakowska (341), makroregionie Wyżyna Woźnicko-Wieluńska (341.2), mezoregionie Wyżyna Wieluńska (341.21). W literaturze geologicznej, a przede wszystkim turystycznej, możemy spotkać się z określeniami omawianego obszaru jako Wyżyny Krakowsko-Wieluńskiej lub Wyżyny Wieluńskiej. W starszych przewodnikach turystycznych można spotkać się z podejściem, że częścią właściwą i istotną turystycznie jest obszar między Krakowem a Częstochową (Jura Krakowsko-Częstochowska), zaś o Wyżynie Wieluńskiej wspomina się raczej zdawkowo. Problem ten może wynikać z przejściowości krajobrazu Wyżyny Woźnicko-Wieluńskiej, pomiędzy wyżynnym a nizinnym.
Pomimo, że obszar jako całość przypisywany jest do Wyżyn Polskich, to jednak od strony krajobrazowej można uznać, że charakter typowo wyżynny, wyraźnie widoczny w terenie, mają tylko nieliczne miejsca. Dobrym przykładem przejściowości krajobrazu Wyżyny Woźnicko-Wieluńskiej są Pagóry Kłobuckie. Tam prócz stoliw kemowych ukształtowanych podczas arealnej deglacjacji lądolodu odrzańskiego uwidaczniają się pagóry wapienne. Są one „reprodukowane” w pokrywie plejstoceńskiej lub odsłonięte w części wierzchowinowej (Klimek 1966). Teren ten charakteryzuje się również silnym krasowieniem podziemnym, o czym świadczy koncentracja lejów krasowych reprodukowanych w pokrywie plejstoceńskiej (Nowak 1993, Hałka 2009).

Problem z klasyfikacją (do krain) pojawia się dosyć często. Na przykład północny skraj Wniesień Łódzkich nazywany był Wyżyną Łódzką (Klatkowa 1972, Dylikowa 1973). Ze względu na wymagane cechy, takie jak budowa geologiczna i wysokość nad poziomem morza, teren ten nie mógł być zaliczony do obszaru wyżynnego. Powszechnie w Polsce przyjmuje się, że obszar wyżynny powinien być położony powyżej $300 \mathrm{~m}$ n.p.m., zbudowany z niepofałdowanych skał litych. W przypadku „Wyżyny Łódzkiej” jej 
wysokość maksymalna wynosi 280 m n.p.m., zaś zbudowana jest z ponad 100 metrów miąższości osadów lodowcowych i wodnolodowcowych, często silnie zaburzonych (Turkowska 2006a). Pomimo tego od strony krajobrazowej np., na terenie Lasu Łagiewnickiego w Łodzi, można znaleźć wiele miejsc (fot. 1) przypominających krajobraz wyżynny (Jaskulski i Szmidt 2015).

Inna sytuacja występuję w przypadku północnej części Wyżyny Wieluńskiej (ryc. 1A, ryc. 1B), zaś od strony krajobrazu sprawia wrażenie obszarów nizinnych o równinnym lub lekko pagórkowatym charakterze (fot. 2). Co istotne, na Wyżynie Wieluńskiej jest najwięcej miejsc, gdzie spod pokrywy plejstoceńskiej ukazują się formy wapienne (przełomy Warty w Mstowie i k. Działoszyna) lub są „reprodukowane” w pokrywie plejstoceńskiej (Pagóry Kłobuckie). Wprawdzie wysokości bezwzględne wahają się w przedziale 220-280 m n.p.m., to jednak niewiele jest miejsc, gdzie wzniesienia przekraczają 300 m n.p.m. Podłoże starsze zbudowane jest z osadów górnojurajskich, głównie wapieni, jednakże w większości pokryte jest osadami czwartorzędowymi o znaczącej miąższości (ryc. 2, ryc. 3). Rzeźba wyżynna nie posiada tak wyrazistego charakteru jak np. pomiędzy Częstochową a Krakowem (np. liczne wysokie formy skałkowe). W związku z tym za najważniejszą atrakcję turystyczną analizowanego obszaru należy uznać występowanie licznych podziemnych form krasowych, które w większości zostały objęte ochroną rezerwatową.

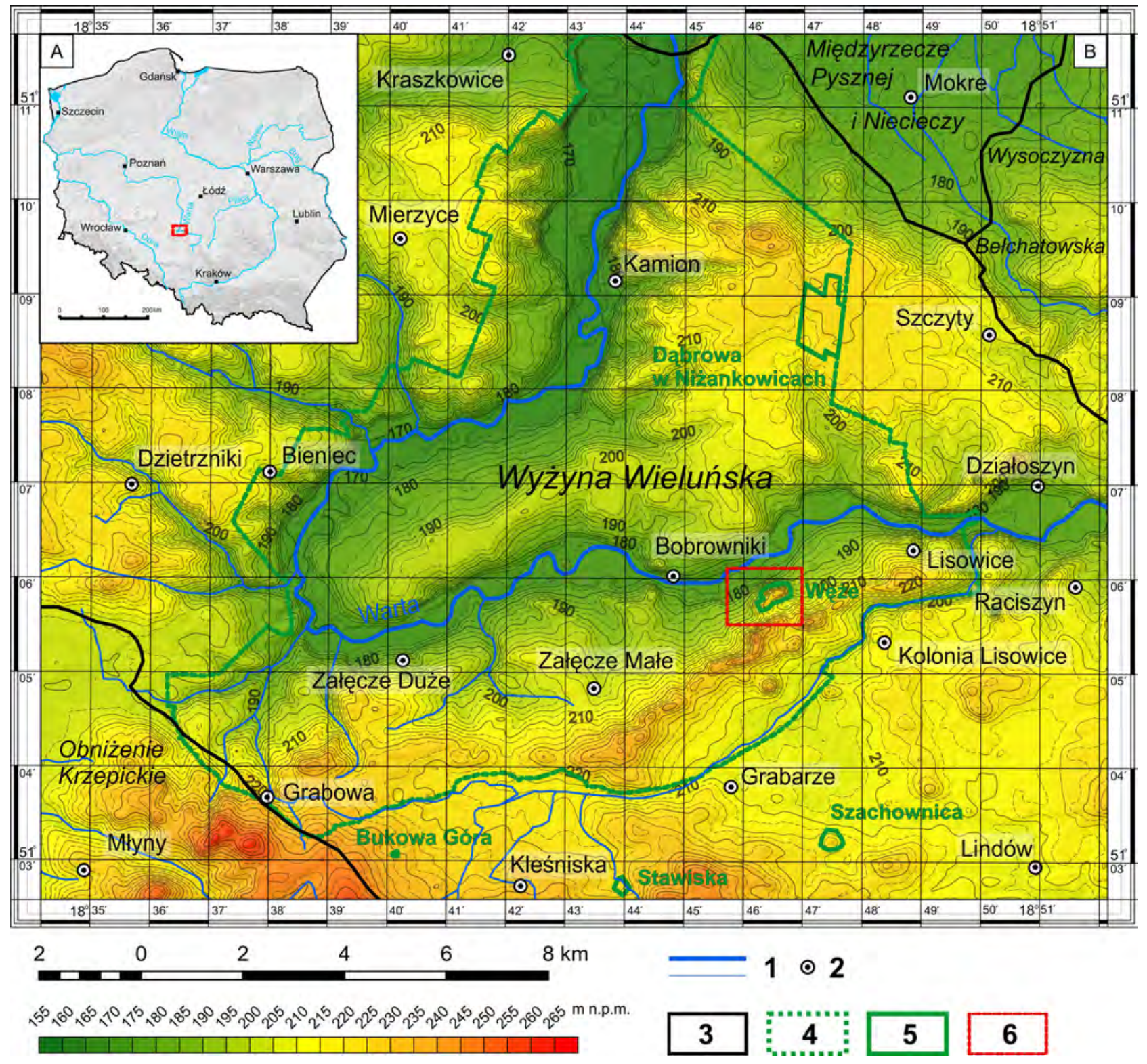

Ryc. 1. Położenie obszaru badań: A - na terenie Polski, B - na tle regionalizacji fizycznogeograficznej (Solon i in. 2018) oraz ukształtowania powierzchni terenu: 1 - rzeki, 2 - miejscowości, 3 - granice mezoregionów, 4 - granice Załęczańskiego Parku Krajobrazowego, 5-granice rezerwatów, 6 - obszar badań

Fig. 1. Location of the research area: A - in Poland, B - against the background of physico-geographical regionalization (Solon et al. 2018) and landforms: 1 - rivers, 2 - towns, 3 - borders of mesoregions, 4 - borders of the Załęczański Landscape Park, 5 - borders of reserves, 6 - research area 


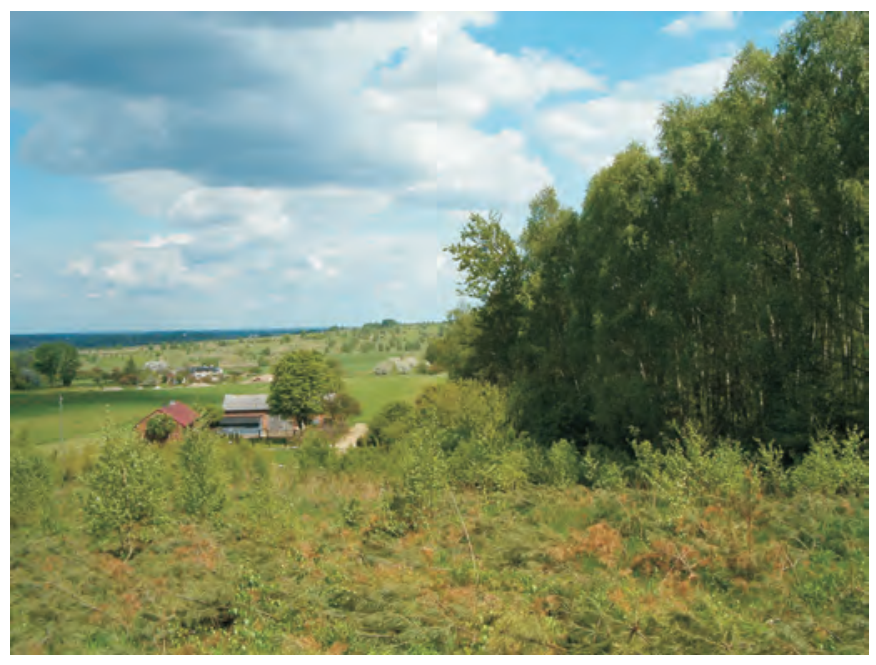

Fot. 1. Północna krawędź Wzniesień Łódzkich (fot. A. Szmidt, 2008) Photo 1. Northern escarpment of Łódź Heights (photo by A. Szmidt, 2008)

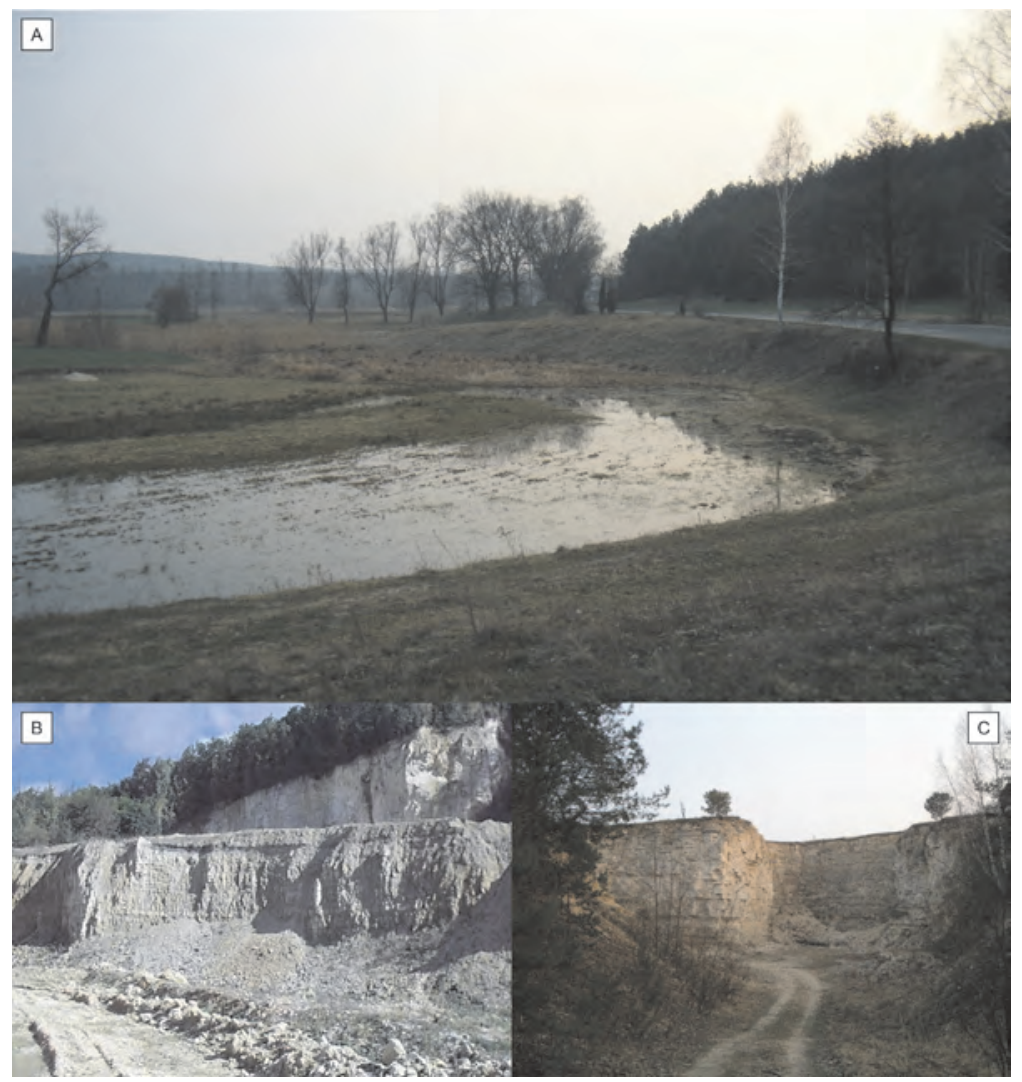

Fot. 2. A - Dolina Warty $w$ okolicach Bobrownik (fot. A. Szmidt, 2006), B - Kamieniołom "Warta” (fot. A. Szmidt, 2014), C - Kamieniołom w Lisowicach (fot. A. Szmidt, 2006)

Photo 2. A - The Warta valley near Bobrowniki (photo by A. Szmidt, 2006), B - "Warta" Quarry (photo by A. Szmidt, 2014), C - Quarry in Lisowice (photo by A. Szmidt, 2006)

\section{2. Źródła danych i metody badań}

W przypadku prac terenowych wykonano dokumentację fotograficzną. Drugim etapem prac były operacje i analizy w Systemach Informacji Geograficznej (GIS).

Dla wizualizacji ukształtowania powierzchni terenu dla obszaru Polski użyto numerycznego modelu terenu o rozdzielczości siatki co najmniej 100 m udostępnianego przez Główny Urząd Geodezji i Kartografii (GUGiK). Pobrane zasoby w postaci tabel X, Y, Z zostały zaimportowane poprzez program SAGA GIS 2.3.2 (funkcja: Import/Export/Grids/ Import Grid from XYZ). Po wczytaniu wszystkich warstw, rastry zostały połączone (funkcja: Grid/Tools/Mosaicking), a następnie raster wynikowy wyeksportowany do forma- tu Golden Software Surfer (funkcja: Import/Export/Grids/ Export Surfer Grid). Ta sama procedura została wykonana dla innych danych morfometrycznych dostępnych w formie tabelarycznej. Wstępnej wizualizacji ukształtowania powierzchni terenu na prezentowanych mapach (metoda warstwobarwna z cieniowaniem) dokonano w programie Golden Software Surfer 14 poprzez nałożenie z przezroczystością na siebie mapy barwnej i mapy cieniowania. Generalizację rysunku poziomicowego dokonano w oparciu o reinterpolację danych metodą lokalnego wielomianu (local polynomial) w programie Golden Software Surfer. Jako źródło danych do uzyskania mapy miąższości czwartorzędu wykorzystano Mapę geologiczną Polski bez utworów czwartorzędu w skali 1:200 000 arkusz Kluczbork, 
wyd. B (Haisig i in. 1979). Rysunek poziomicowy został zdigitalizowany ręcznie, a następnie na jego podstawie wyinterpolowano raster w programie Esri ArcGIS 10.5. (metoda: Topo to Raster). Dalej utworzono raster wynikowy poprzez odjęcie od powierzchni współczesnej (raster o rozdzielczości co najmniej $25 \mathrm{~m}$ ), powierzchni kopalnej (funkcja: ArcToolbox/Spatial Analyst Tools/Math/Minus). Mapę geomorfologiczną uzyskano poprzez ręczną digitalizację Mapy geomorfologicznej regionu łódzkiego (Turkowska 2006b), a następnie przetworzenie i generalizację jej do schematu mapy geomorfologicznej Polski w skali 1:100 000 (Turkowska i Szmidt 2014). Ostatecznie mapy wynikowe złożono w programie Corel Draw X7.

Analizując literaturę naukową dotyczącą Góry Zelce, najważniejsze badania prowadzono $w$ drugiej połowie XX wieku. Jednak już w latach 30. XX wieku Samsonowicz (1934) opisał szczątki zwierzęce z okresu trzeciorzędu, odkryte w 1933 roku we wzgórzu zwanym wtedy Górą Zelcową. Przy eksploatacji wapienia krystalicznego na potrzeby pobliskiej huty szkła natrafiono tam na lej wypełniony warstwami brekcji kostnej. Lej ten był prawdopodobnie pozostałością po jaskini, zamieszkiwanej ongiś przez różne zwierzęta, której strop uległ z czasem zniszczeniu, a cała jaskinia została zawalona rumowiskiem skalnym.

Badania przyrodnicze prowadzone na obszarze Załęczańskiego Parku Krajobrazowego koncentrowały się głównie na opracowaniu dokumentacji naukowej flory i roślinności tego terenu (Olaczek i Czyżewska 1986, Czyżewska i Olaczek 1992).

Bardzo dobrze udokumentowana jest także paleogeografia Wyżyny Wieluńskiej, m.in. dzięki wieloletnim badaniom Krzemińskiego (1965, 1986). Zagadnienia rozwoju form krasowych doskonale opisane są przez Szynkiewicza (1971, 1977), Szynkiewicza i in. (2015), Szelerewicza i Górnego (1986) oraz Zadwornego (1974, 1977). Doskonałym opracowaniem popularyzującym krasową rzeźbę na tym terenie jest także publikacja Szynkiewicza (2014). Zawarto tam obszerną dokumentację fotograficzną oraz kartograficzną jaskiń wraz z przekrojami przez namuliska oraz dokumentację fotograficzną kamieniołomów w okolicach Działoszyna.

Wybrane walory abiotyczne Załęczańskiego Parku Krajobrazowego, w tym rezerwatu „Węże”, w obszerny sposób wraz z dokumentacją fotograficzną przedstawia wiele doniesień naukowych realizowanych w Uniwersytecie Łódzkim (Cyrek 1996, Bezkowska i in. 1999, Krysiak i Majchrowska 2001, Papińska 2001a, 2001b, Papińska i Tołoczko 2002, Krysiak i Papińska 2005).

Laskowski i in (2001) do badań szczegółowych Załęczańskiego Parku Krajobrazowego wyznaczyli 13 stanowisk, na których oprócz opisu profili glebowych określono formę terenu, rodzaj skały macierzystej gleb, warunki wilgotnościowe, sposób użytkowania terenu oraz roślinność z podkreśleniem gatunków dominujących. Trzy stanowiska znajdowały się w rezerwacie „Węże”. Z kolei Tołoczko i Szmidt (2018) przedstawili charakterystykę i genezę form litologicznych Działoszyńskiego Łuku Warty oraz wyniki badań gleboznawczych na Górze Zelce. W profilach określono fizyczne i chemiczne właściwości gleb. W rezerwacie „Węże” na badanej powierzchni 0,2 km² występuje zróżnicowanie składu granulometrycznego rędzin - od piaskowej do gliniastej. W większości badane gleby zostały sklasyfikowane jako rędziny brunatne.
W literaturze dominowały opracowania badań z zakresu szeroko rozumianej biologii, geologii, geologii czwartorzędu, paleontologii, geomorfologii oraz gleboznawstwa. Co istotne, pomimo bogatych badań i związanych z nimi publikacjami, licznymi dokumentacjami, niewiele można znaleźć powszechnie dostępnych opracowań pokazujących zdjęcia jaskiń będących tutaj podmiotem badań. Zarówno w literaturze, jak i na tematycznych stronach internetowych zagadnienia związane z Górą Zelce są często opisywane, ale słabiej udokumentowane fotograficznie.

Celem badań przedstawionych w tym artykule było dokonanie próby przybliżenia wiedzy o Górze Zelce w oparciu o nowsze opracowania kartograficzne oraz unikalną dokumentację fotograficzną wnętrza jaskiń.

\section{Budowa geologiczna i rzeźba terenu Wyżyny Wieluńskiej}

Geologicznie Wyżyna Wieluńska położona jest w obrębie monokliny śląsko-krakowskiej (Pożaryski 1974, Stupnicka 1997). W przypadku obszaru badań i jego sąsiedztwa w podłożu osadów kenozoicznych dominują iły, mułowce i piaskowce z syderytami (jura środkowa) oraz osady wapienno-margliste (jura górna). Ze względu na większą odporność na procesy wietrzenia, na powierzchni lub blisko niej, możemy spotkać najczęściej wapienie płytowe oraz skaliste. Najwyższe wzniesienia zbudowane są z bardziej odpornych na wietrzenie wapieni skalistych. Miejsca te stanowiły dawniej obszary eksploatacji wapieni. Obecnie czynne są tylko największe kamieniołomy, takie jak „Warta” pracujące dla potrzeb przemysłu cementowego lub w Raciszynie dla potrzeb przemysłu kamieniarskiego i drogowego.

Pierwotnie osady ułożone były horyzontalnie. Pod koniec kredy nastąpiła regresja morza zaś osady zostały pocięte systemem uskoków (Głazek i in. 1977). Linie te stanowiły początek systemu krążenia wody i zawartych w nich substancji chemicznych, takich jak: kwas węglowy lub kwasy organiczne. W neogenie i paleogenie na badanym obszarze ścierały się zarówno procesy geomorfologiczne lądowe, jak i wodne. Część zachodnia zdominowana była przez procesy związane z istnieniem zbiornika wodnego (akumulacja), w części zachodniej - lądowej rozwijały się procesy krasowe. Szczególnym impulsem było działanie tektoniki nieciągłej, dzięki której mógł przekształcać się system podziemnego krążenia wód (Dynowska 1983, Krzemiński 1986).

W oligocenie i miocenie tektonika potomna utworzyła szereg nowych zrębów, których efektem było pionowe przesunięcie bloków skalnych. Powstałe różnice w wysokościach względnych i związane z tym różnice w energii, wzmogły działanie procesów erozji. Elementami tej rzeźby są zarówno formy pozytywne, takie jak ostańce oraz formy wklęsłe jak polja. Mniej widoczny w terenie, chociaż najbardziej efektowny, jest kras podziemny w formie jaskiń i ich osadów.

Można założyć, iż pod koniec neogenu na Wyżynie Wieluńskiej ukształtował się krajobraz krasowy starszy, charakteryzujący się mocno zdenudowanymi wzniesieniami, dolinami rzecznymi i silnie rozwiniętym, lecz wypełnionym w dużej mierze krasem podziemnym. 
Istotny wpływ na krajobraz Wyżyny Woźnicko-Wieluńskiej miały zlodowacenie odry, zaś północnej części tego regionu zlodowacenie warty. W pierwszej kolejności powierzchnia neogeńska podlegała procesom egzaracyjnym, których ślady można zaobserwować na skałkach kulminacji ostańców (Krzemiński 1974, 1986, Papińska 2001a). Starsze lite podłoże modyfikowało przebieg ruchu lądolodu. Masy lodu preferowały do ruchu istniejące już wcześniej doliny rzeczne, wzgórza zaś sprzyjały jego rozchodzeniu. Szczególną rolę odgrywały wtedy doliny Pra-Prosny, Pra-Warty i Pra-Widawki (Baraniecka i Sarnacka 1971, Lewandowski 1982).

Wcześniejsze badania Wyżyny Woźnicko-Wieluńskiej zostały istotnie uzupełnione przez Szuberta (2012). Między innymi dzięki wynikom badań geostatystycznych wykonanych w Systemach Informacji Geograficznej (GIS), autor wskazał, że powierzchnia podplejstoceńska ukształtowana w starszych cyklach morfogenetycznych, w istotny sposób została przemodelowana w czasie zlodowacenia odry, przez procesy erozyjne związane z wodami subglacjalnymi. Dobre udokumentowanie dużych różnic wcięć rynien subglacjalnych pozwoliło na podważenie starszych poglądów na fluwialną genezę rozcięć erozyjnych i istotną rolę ruchów neotektonicznych.

Ostatnim zdarzeniem glacjalnym było zlodowacenie warty. Co istotne, w jego wyniku pozostały nie tylko osady typowo glacjalne, lecz również fluwioglacjalne. Przypuszcza się, że na elewacjach podłoża starszego mogły powstawać przetainy, gdzie akumulowały się osady z topniejącego lądolodu. Można też przypuszczać, że w okresie tym mogły istnieć ruchy izostatyczne podłoża oddziaływujące na naprężenia w pokrywie lodowej i powstawanie np. pęknięć. Na wpływ taki wskazuje się również na obszarach niżowych (Klajnert 1978, Jaksa i Szmidt 2008). W efekcie tych procesów w sąsiedztwie Góry Zelce i północnej części Wyżyny Wieluńskiej występują formy teras, wałów kemowych oraz powierzchni sandrowych (Klimek 1966, Krzemiński 1974) (ryc. 2).

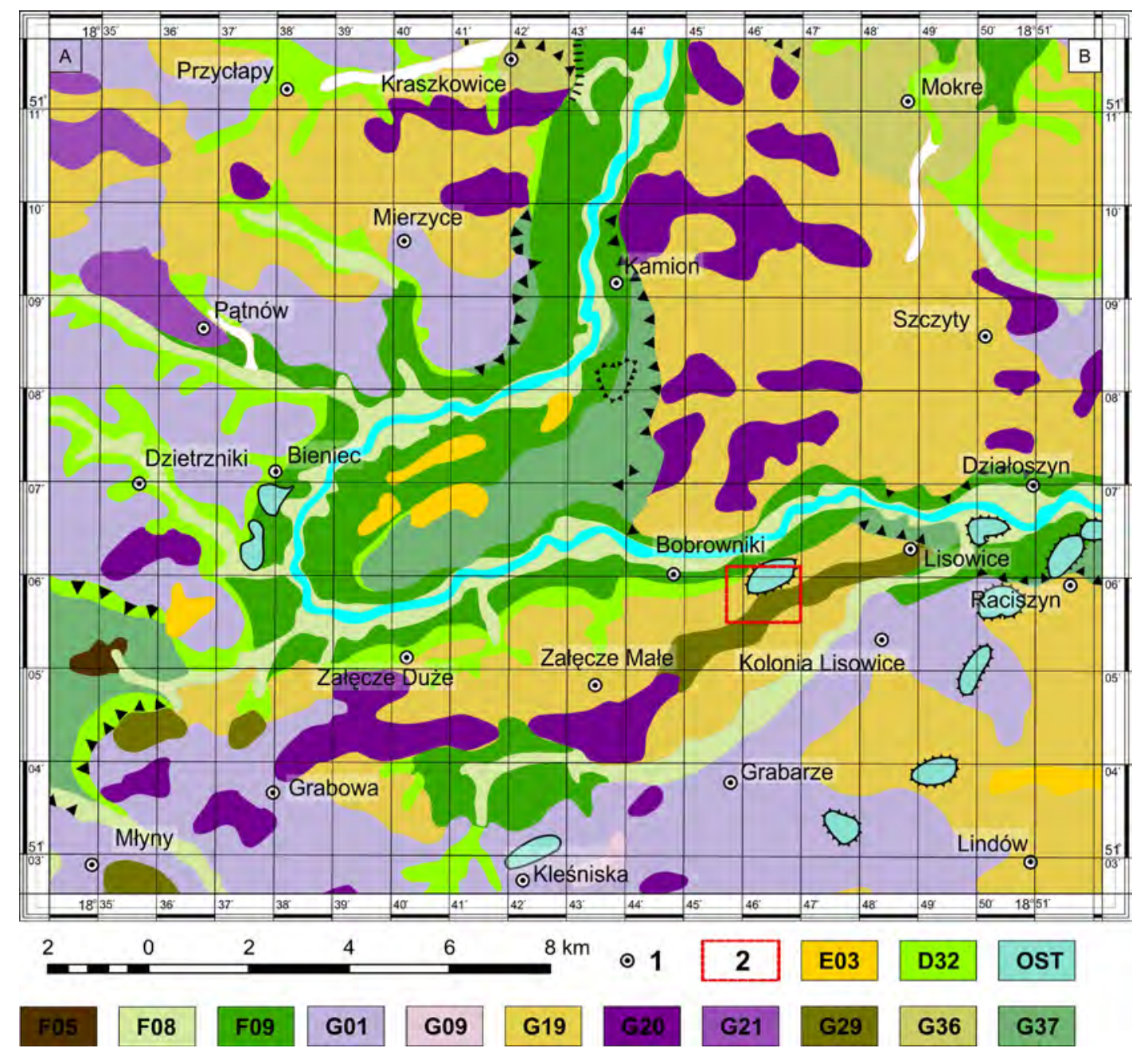

Ryc. 2. Mapa geomorfologiczna okolic Załęczańskiego Przełomu Warty: 1 - miejscowości, 2 - obszar badań, E03 - wydmy, D32 - doliny denudacyjno-erozyjne, OST - ostańce górno jurajskie, F05 - równiny biogeniczne, F08 - terasa zalewowa, F09-terasy nadzalewowe, G01 - wysoczyzny morenowe, G09 - zagłębienia końcowe, G19 - równina lub szlak sandrowy, G20 - morena czołowa akumulacyjna, G21 - morena czołowa spiętrzona, G29 - kemy i stoliwa przetainowe, G36 - równina erozyjna wód roztopowych, G37 - terasa pradolinna (oprac. własne na podstawie (Turkowska 2006b, Turkowska i Szmidt 2014)

Fig. 2. Geomorphological map of the vicinity of the Załęcze gorge of the Warta: 1 - localities, 2 - research area, E03 - dunes, D32 - denudation and erosion valleys, OST - Upper Jurassic inselbergs, F05 - biogenic plains, F08 - floodplain, F09 - terraces, G01 - moraine plateaus, G09 - final terminal basin, G19 - outwash plain (sandur) or outwash track, G20 - accumulative moraine, G21 - thrust moraine, G29 - kame and kame plateau, G36 - meltwater erosional plain, G37 - ice-marginal valley terrace (own study based on (Turkowska 2006b, Turkowska and Szmidt 2014) 
W okresie zlodowacenia wisły w dolinach rzecznych dominowały procesy akumulacji związane z zatamowaniem odpływu wód ekstraglacjalnych w kierunku północnym. W okresie holocenu w dolinach rzecznych przebiegały procesy erozji, zaś poza nimi procesy erozji i denudacji. W rejonie stoków dolinnych można zaobserwować szereg rozcięć wąwozowych (ryc. 2, ryc. 4). Duża ilość osadów piaszczystych genezy glacifluwialnej stała się źródłem zasilania dla osadów eolicznych. Analizując rozmieszczenie form geomorfologicznych (ryc. 1, ryc. 2.) można stwierdzić, że analizowany obszar w zdecydowanej większości pokryty jest osadami czwartorzędowymi, gdzie tylko miejscami na powierzchni odsłaniają się osady jurajskie. Obszarowo dominują osady glacifluwialne (G19) oraz wysoczyzny morenowe (G01). Dominującymi morfometrycznie formami terenu są moreny czołowe akumulacyjne (G20) oraz kemy i stoliwa przetainowe (G29). Ma to przełożenie w miąższościach osadów czwartorzędowych (ryc. 3). Największe miąższości do $80 \mathrm{~m}$ czwartorzęd osiąga na północ i zachód od Załęczańskiego Przełomu Warty oraz w strefie czołowo morenowej, bezpośrednio na południe od Góry Zelce.

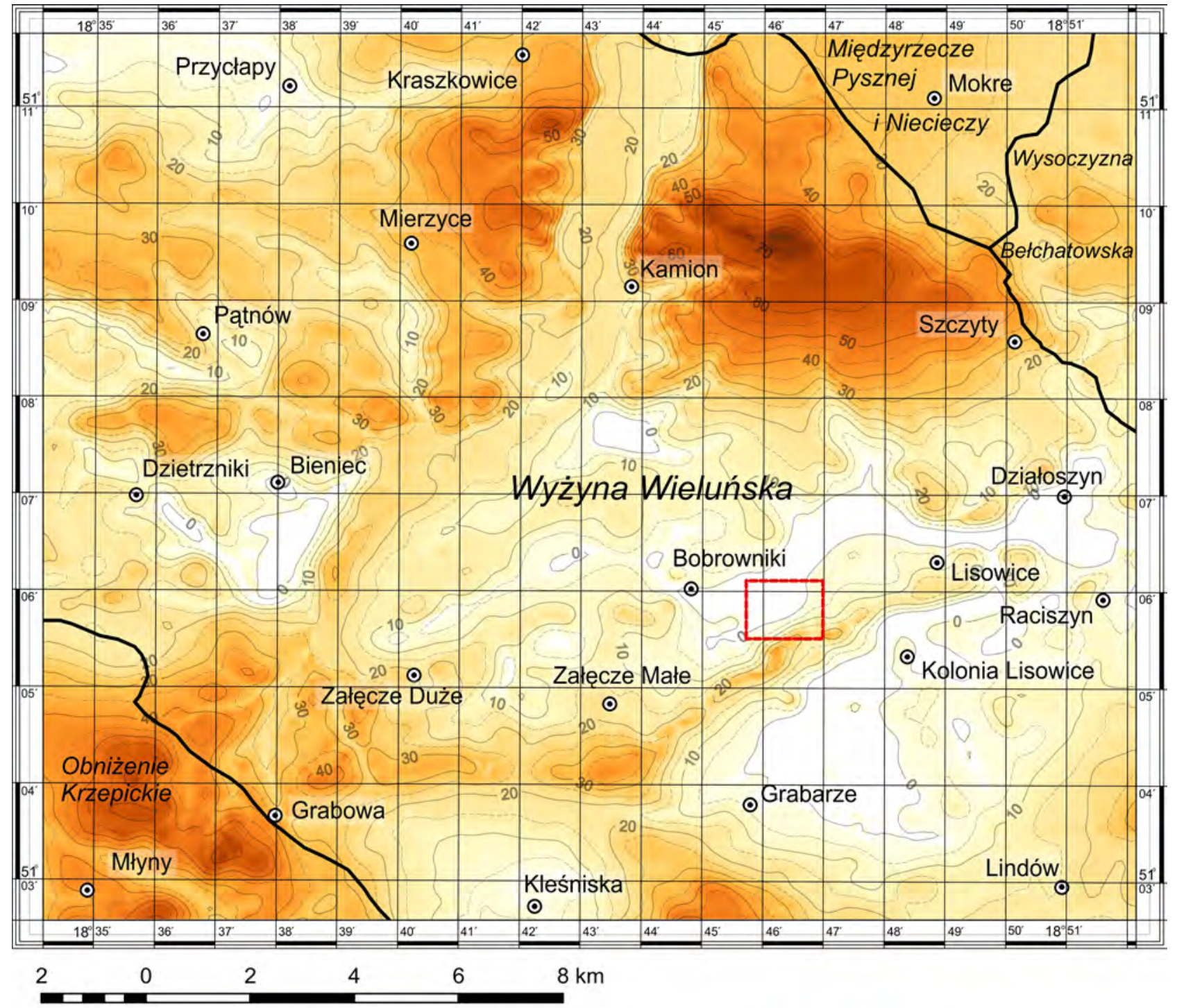

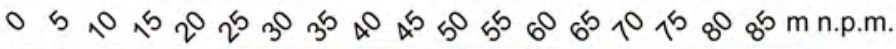

Ryc. 3. Miąższość osadów czwartorzędu okolic Załęczańskiego Przełomu Warty: 1 - granice mezoregionów, 2 - obszar badań, 3 - miejscowości (oprac. własne na podstawie Haisig i in. 1979 i danych GUGiK udostępnianych bez opłat)

Fig. 3. Thickness of the Quaternary sediments around the Załęcze gorge of the Warta: 1 - borders of mesoregions, 2 - research area, 3 - towns (own study based on Haisig et al. 1979 and GUGiK data available free of charge) 


\section{Atrakcyjność geoturystyczna Załęczańskiego Parku Krajobrazowego}

Wiele jaskiń Wyżyny Wieluńskiej zostało odkrytych dzięki poszukiwaniom złóż geologicznych, w szczególności kalcytu stanowiącego niegdyś ważny składnik dla przemysłu hutniczego. To, co było impulsem ich odkrycia stało się jednocześnie początkiem ich zagłady. Formacje naciekowe zostały w większości zniszczone. O pięknie jaskiń na Wyżynie Wieluńskiej możemy wnioskować głównie z opisów w starszych publikacjach (Samsonowicz 1934, Szynkiewicz 1971) oraz licznych, ale bardzo małych hałd wokół wyeksploatowanych jaskiń. Do dzisiaj na terenie całej Wyżyny Wieluńskiej spacerując wokół jaskiń możemy w pobliżu ścieżek zaobserwować liczne pokruszone, błyszczące kryształy kalcytu.

Musimy jednak pamiętać, że dawniej kiedy nie była rozwinięta i modna turystyka, obiekty jaskiniowe nie były traktowane jako atrakcja. Uważano je raczej za miejsce schronienia dla ludzi, zwierząt lub przechowywania towarów, a istniejącą tam szatę naciekową, czy namuliska jako źródło pozyskania surowca skalnego lub nawozu dla rolnictwa. Amatorska eksploracja jaskiń w Polsce na masową skalę rozpoczęła się w dwudziestoleciu międzywojennym, zaś swoje apogeum osiągnęła w okresie lat 60.-70. XX wieku. Stowarzyszenia i organizacje turystyczne dokonywały w jaskiniach oznaczeń ścieżek, czasami przekopów na bardziej ciasnych odcinkach korytarzy (zaciski), a na trudniejszych i często pionowych odcinkach umieszczano łańcuchy lub drabiny.

W związku z tym, większość jaskiń w Polsce o układzie poziomym, względnie pochyłym (jaskinie bezpieczne) zostały udostępnione dla ruchu turystycznego. Z czasem, ze względów bezpieczeństwa, ochrony zimowisk nietoperzy i przepisów prawa, większość tego typu obiektów na obszarze Polski została zamknięta do samodzielnego zwiedzania. Najczęściej wejścia do nich są okratowane, zaś drzwi w kratach posiadają na tyle mały otwór wejścio- wy, że aby go pokonać należy być do tego odpowiednio przygotowanym fizycznie, jak i sprzętowo. W następstwie tego, większość mniej znanych jaskiń w Polsce jest zamknięta dla powszechnego ruchu turystycznego, a wiedzę o nich (jak już wspomniano) możemy zdobywać ze starszych przewodników turystycznych lub krótkich opisów zamieszczonych na stronach internetowych.

W literaturze opisuje się, że na Górze Zelce zidentyfikowano 10 jaskiń (Szynkiewicz 1977, Szelerewicz i Górny 1986, Papińska 2001a). Należy jednak pamiętać, że wiele z nich zostało odkrytych dzięki pracom górniczym. Skoro w nienaturalny sposób znalazły się one na powierzchni terenu, to podlegają na nowo silnym procesom wietrzenia.

Należy tutaj wydzielić kilka podstawowych procesów. Pierwszym z nich jest efekt odprężeniowy związany z odsłonięciem mas skalnych przez prace górnicze. Powoduje to dodatkowe spękania skał umożliwiające lepsze wnikanie wody wraz ze składnikami chemicznymi (Migoń 2006). Odsłonięte systemy jaskiniowe w początkowych odcinkach ulegają również wietrzeniu mrozowemu, doprowadzającemu do blokowego rozpadu skał. Prace górnicze, szczególnie przy użyciu materiałów wybuchowych, naruszają strukturę skał powodując liczne uszkodzenia we wnętrzu jaskiń. W Polsce znany jest przypadek zamknięcia dużych kamieniołomów w Kletnie w Kotlinie Kłodzkiej, gdzie wstrząsy podczas prac górniczych zagrażały stabilności Jaskini Niedźwiedziej. W wyniku działalności człowieka oraz procesów naturalnych na Górze Zelce, z 10 zidentyfikowanych jaskiń można łatwo zlokalizować 7 (Jóźwiak 2007), zaś w ramach powszechnego ruchu turystycznego, spacerując i podziwiając otaczający krajobraz, można dotrzeć do 5 .

\section{Charakterystyka wybranych jaskiń}

Poniżej przedstawiono jaskinie jako obiekty geoturystyczne i ich lokalizację z uwzględnieniem ukształtowania powierzchni wokół Góry Zelce (ryc. 4).

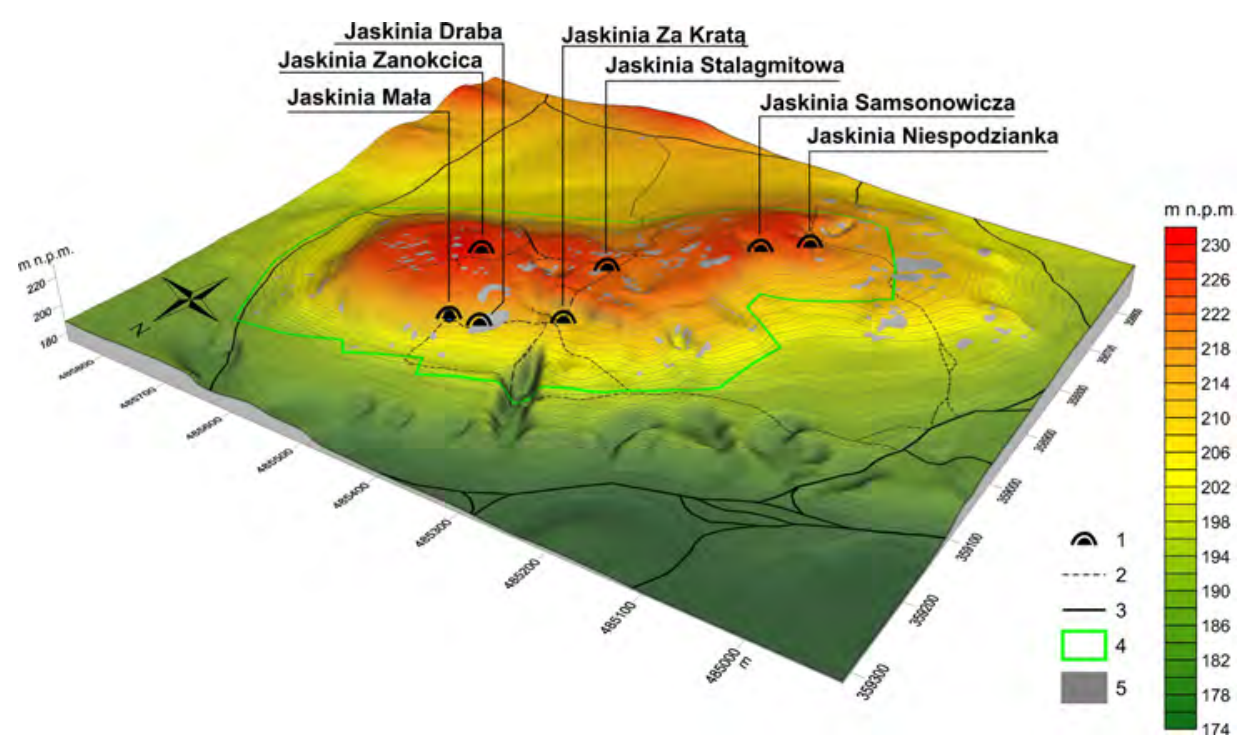

Ryc. 4. Lokalizacja wybranych jaskiń na Górze Zelce na tle ukształtowania powierzchni terenu: 1 - jaskinie, 2 - ścieżki, 3 - drogi gruntowe, 4 - granice rezerwatu „Węże”, 5 - obszary prac górniczych

Fig. 4. Location of selected caves on the Zelce hill in relation to the terrain: 1 - location on the caves, 2 - paths, 3 - tracks, 4 - borders of the "Węże" reserve, 5 - mining areas 


\section{Jaskinia Niespodzianka}

Jest to pierwsza jaskinia w pobliżu niebieskiego szlaku biegnącego od strony doliny Warty na szczyt Góry Zelce. Otwór wejściowy (fot. 3A) znajduje się od strony zachodniej wzgórza na wysokości około 217 m n.p.m., w miejscu dawnego niewielkiego kamieniołomu (Szelerewicz i Górny 1986, Jóźwiak 2007, Szynkiewicz i in. 2015), a wokół widoczne są jeszcze liczne ślady prac górniczych. Jaskinia była miejscem eksploatacji kalcytu dla potrzeb przemysłu, dlatego obecna szata naciekowa jest dość uboga. Resztek szaty nie uchroniło też zasypanie przez dłuższy czas otworu wejściowego. Według badań speleologicznych, w tej jaskini dostępny jest najdłuższy do zwiedzania korytarz na Górze Zelce (około $100 \mathrm{~m}$ ). Istniejące resztki kalcytu (fot. 3B) posiadają różną barwę - od białej poprzez rdzawą, po czerwoną - co wskazuje na zmienne warunki klimatyczne podczas aktywnego funkcjonowania systemu jaskiniowego.

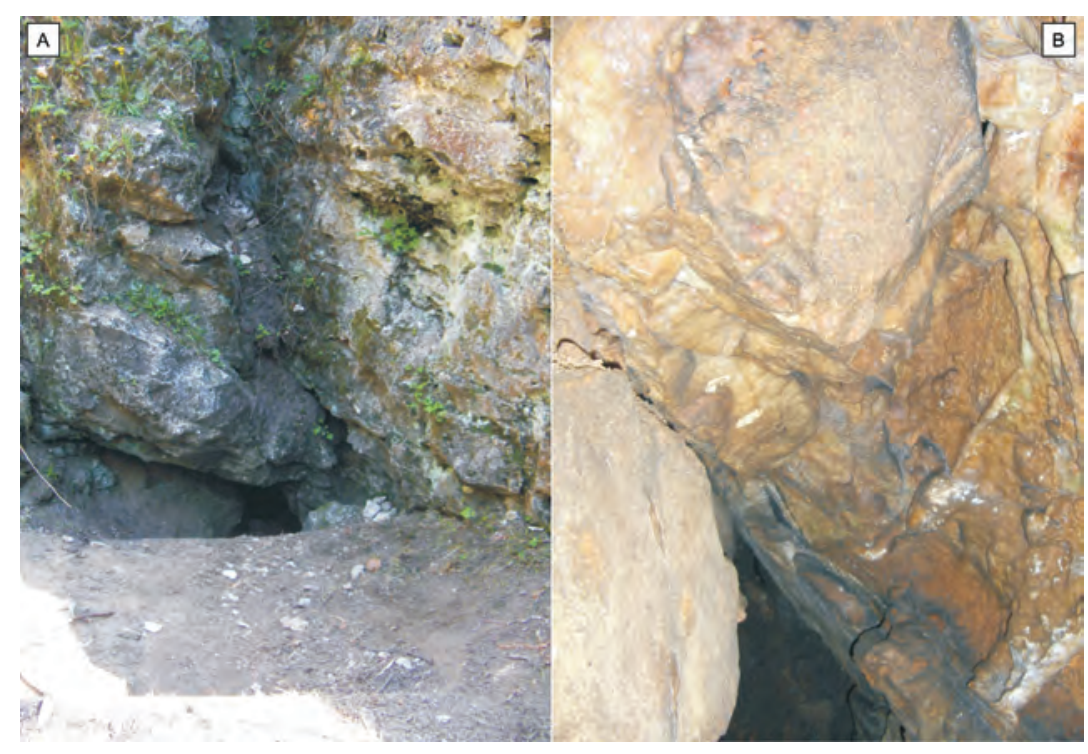

Fot. 3. Jaskinia Niespodzianka: A - wejście do jaskini, B - wnętrze jaskini (fot. K. Jóźwiak, 2007)

Photo 3. Niespodzianka Cave: A - entrance to the cave, B - inside of the cave (photo by K. Jóźwiak, 2007)

\section{Jaskinia Samsonowicza}

Na Górze Zelce najbardziej znaną paleontologicznie jest Jaskinia Samsonowicza (fot. 4). Pierwotnie jaskinia miała formę studni krasowej stanowiącej pułapkę dla licznych zwierząt oraz osadów. Podczas pierwszych badań udokumentowano bogatą faunę plioceńską, gdzie samej brekcji kostnej zebrano ponad 11 ton (Samsonowicz 1934). Podczas badań i prac paleontologicznych z komory jaskiniowej usunięto dużą część osadów, uzyskując przestrzeń o rozmiarach $12 \mathrm{~m}$ długości i około $9 \mathrm{~m}$ głębokości. Przypuszcza się (Szynkiewicz 1977, Szynkiewicz i in. 2015), że obiekt mógł mieć połączenie z resztą systemu jaskiniowego badanej góry. W stropie zachowanych niewielkich korytarzyków, założonych na szczelinach NW-SE i NE-SW, występują interesujące kotły eworsyjne oraz kominki (Szynkiewicz 1977). Istnieje też możliwość, że część tych połączeń została zasypana podczas eksploatacyjnych prac górniczych.

Ze względu na główny układ pionowy i niewielkie rozmiary jaskinię można oglądać z góry ze specjalnie przygotowanego i opisanego stanowiska obserwacyjnego w ramach ścieżki edukacyjnej.

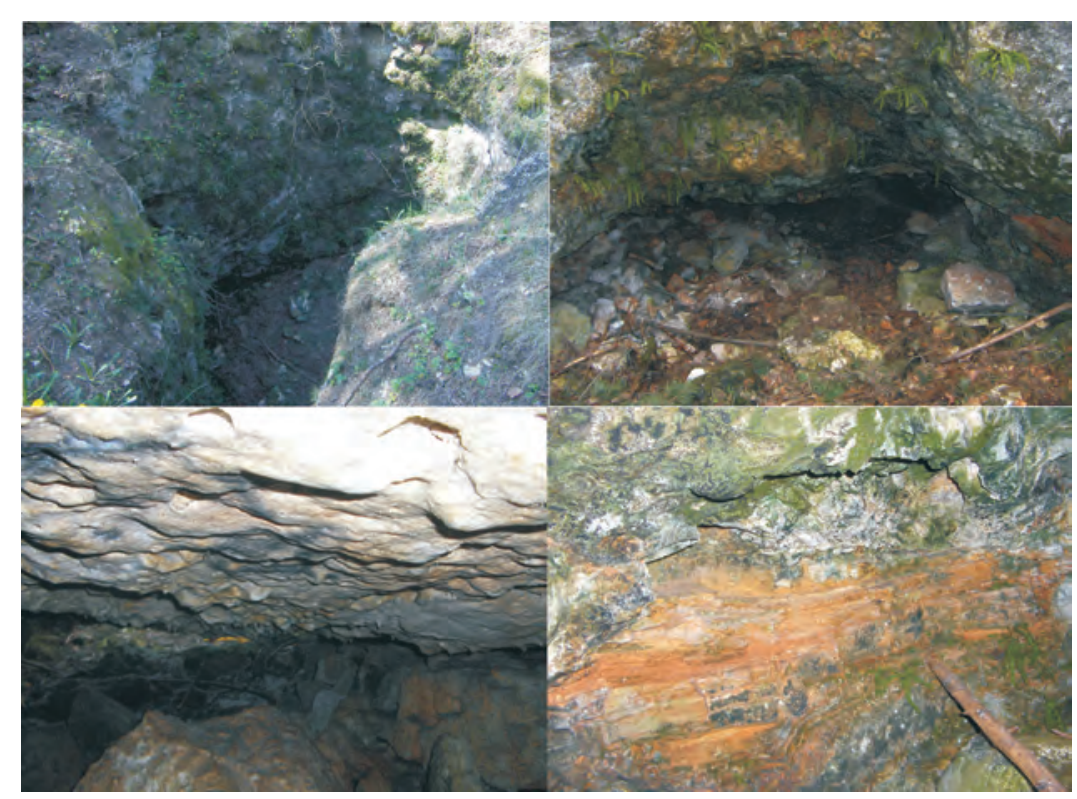

Fot. 4. Jaskinia Samsonowicza (fot. K. Jóźwiak, 2007)

Photo 4. Samsonowicz Cave (photo by K. Jóźwiak, 2007) 


\section{Jaskinia Stalagmitowa}

Jest jedną z ciekawszych jaskiń w obrębie Góry Zelce. Posiada ona pionowy i poziomy układ korytarzy oraz podobnie jak jaskinia Niespodzianka odkryta została dzięki poszukiwaniom kalcytu. Nazwa odnosi się do niezwykłego bogactwa szaty naciekowej, przede wszystkim stalagmitów. Do obecnych czasów pozostały tylko resztki szaty naciekowej w postaci nacieku kalafiorowatego i grzybko- wego oraz buł i guzów nacieków kulistych. W ścianach można zobaczyć jeszcze żyły kalcytu o grubości do 0,3 m (Szynkiewicz 1977). Otwór wejściowy znajduje się w strefie szczytowej wzniesienia (223 m n.p.m.). Ze względów bezpieczeństwa studnia o głębokości 13 m została wyposażona w metalową drabinę. Na dole rozchodzi się szereg niewielkich korytarzy, na dnie których znajdują się namuliska oraz gruz skalny będący pozostałością prac górniczych. Do zwiedzania dostępne jest około 80 m korytarzy (fot. 5).

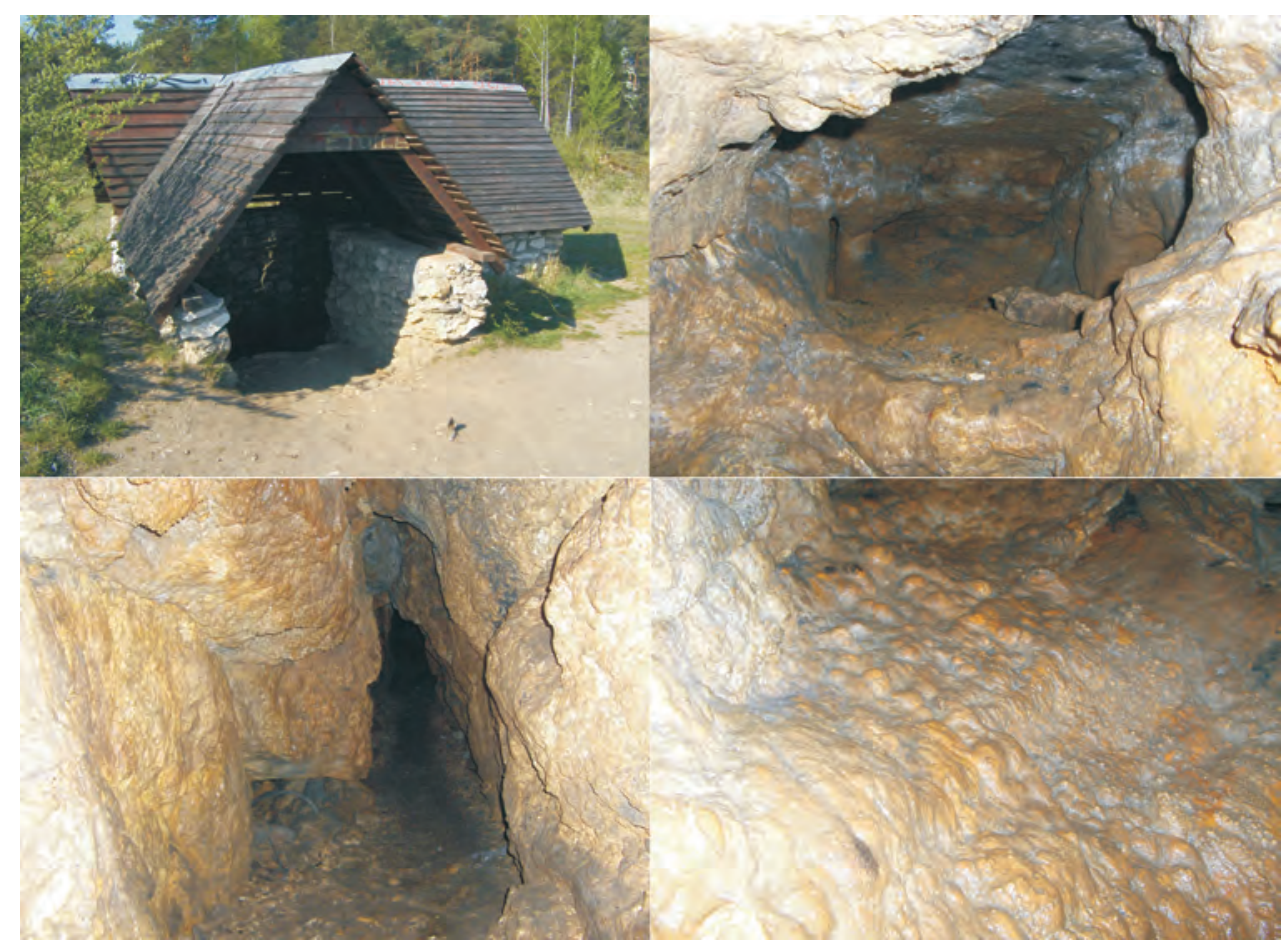

Fot. 5. Jaskinia Stalagmitowa - wejście i wnętrze jaskini (fot. K. Jóźwiak, 2007)

Photo 5. Stalagmite Cave - entrance and interior of the cave (photo by K. Jóźwiak, 2007)

\section{Jaskinia Zanokcica}

Jaskinia znajduje się w strefie szczytowej Góry Zelce (227 m n.p.m.). Stanowi ona pozostałość względnie dużej kopalni kalcytu, która miała mieć wylot na północnych stokach wzniesienia (Szynkiewicz i in. 2015). Obecnie wejście do jaskini zasypane jest gruzem wapiennym (fot. 6).

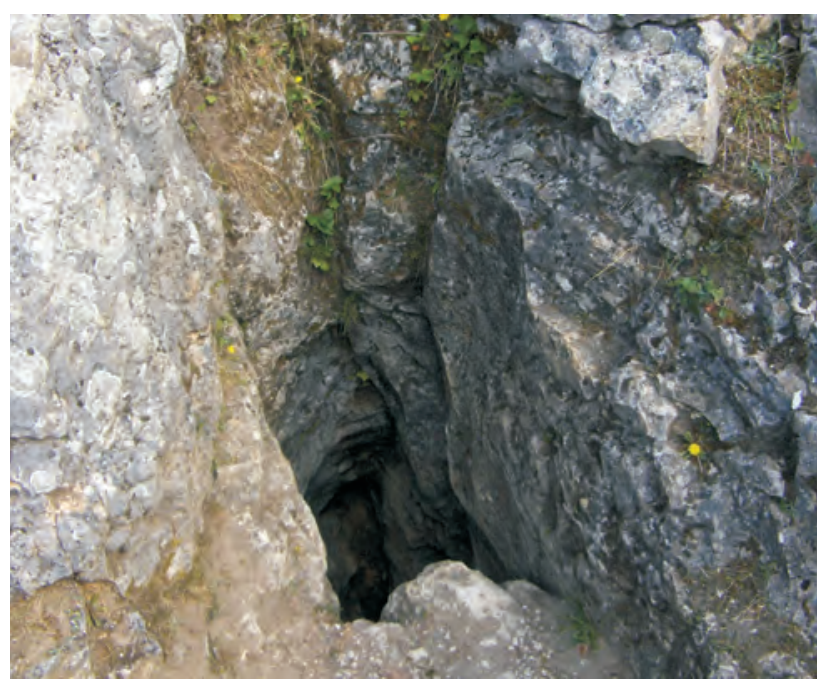

\section{Jaskinia Za Kratą}

Jaskinia zlokalizowana jest na północnym zboczu Góry Zelce. Jest ona dostępna do zwiedzania na dwóch poziomach połączonych pionowymi studniami. Ze względu na układ korytarzy oraz istniejące tzw. zaciski (trudniejsza dostępność turystyczna), w jaskini zachowały się większe pozostałości form naciekowych. Eksploatowano w niej żyłę kalcytu o miąższości ok. 0,3 m. Obecnie do zwiedzania dostępne są korytarze o długości około $70 \mathrm{~m}$ i głębokości około 17,5 m. Do jej wnętrza prowadzi wąska szczelina pomiędzy skałkami, od góry zabezpieczona betonową płytą (fot. 7A), a dalej kręty korytarz, początkowo niski, doprowadza do (wyposażonej w drabinę) 6 metrowej wąskiej studni (fot. 7B, fot. 7C). Pod studnią od strony południowej znajduje się salka ozdobiona formami naciekowymi (fot. 7D). Nacieki reprezentowane są przez fragmenty stalagmitów i stalaktytów, mostków czy żeber (Szynkiewicz i in. 2015). Obecnie powstają stalaktyty rurkowe.

Fot. 6. Otwór wejściowy jaskini Zanokcica (fot. K. Jóźwiak, 2007)

Photo 6. Entrance opening of the Zanokcica Cave (photo by K. Jóźwiak, 2007) 


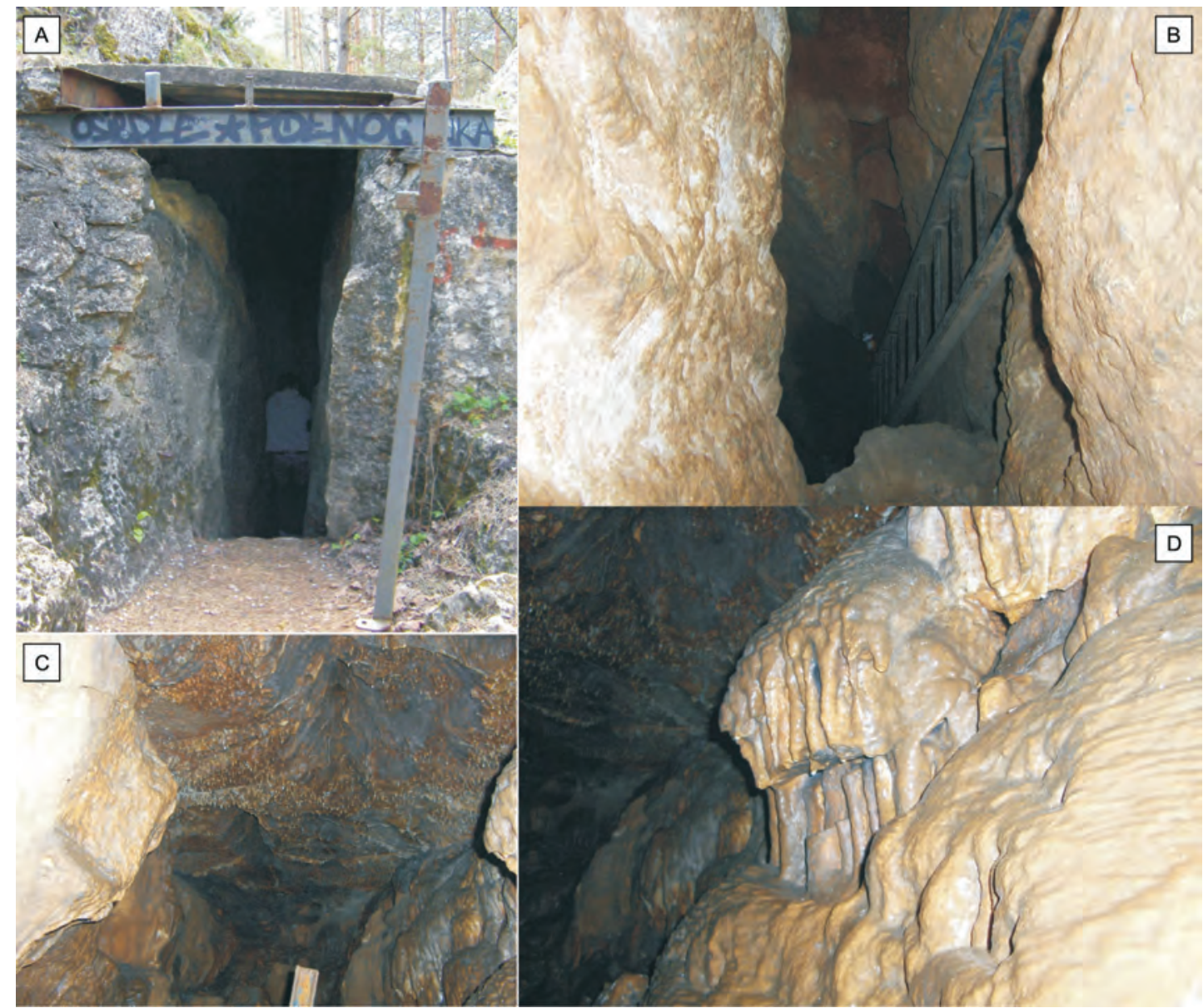

Fot. 7. Jaskinia Za Kratą: A - wejście do jaskini; B, C, D - wnętrze jaskini (fot. K. Jóźwiak, 2007)

Photo 7. Za Kratą Cave: A - entrance to the cave; B, C, D - inside of the cave (photo by K. Jóźwiak, 2007)

\section{Jaskinia Mała}

Wejście do jaskini leży u podstawy ściany dużego wyrobiska na północnym stoku Góry Zelce i odległego o ok. 100 m na NE od Jaskini Za Kratą. Długość korytarzy założonych na systemie spękań o kierunku NW-SE i NE-SW wynosi 26 m, a ich głębokość 4,5 m. Jaskinia po raz pierwszy została wspomniana przez Samsonowicza (1934).

W stropach komór znajdują się kominki ze stalaktytami kulistymi oraz resztkami zniszczonych stalaktytów (fot. 8A, fot. 8C). Jaskinia w znacznej części wypełniona jest ilasto-pylastym namuliskiem (fot. 8B). Barwa osadów zmienia się ku stropowi od brunatno-brązowej do szaro-żółtej. W niektórych laminach stwierdzono szczątki drobnych zwierząt, a w dolnych warstwach natrafiono na stalaktyty bardzo silnie zniszczone przez procesy korozji krasowej. W komorze wstępnej znajduje się warstwa namuliska o grubości ok. 0,7 m zawierająca kości zwierzęce i tworząca skałę o typie czerwonej brekcji kostnej. Stalagmity, które lekko wystają ponad powierzchnię tej polewy noszą również ślady wyraźnej korozji krasowej (Szynkiewicz 1977).
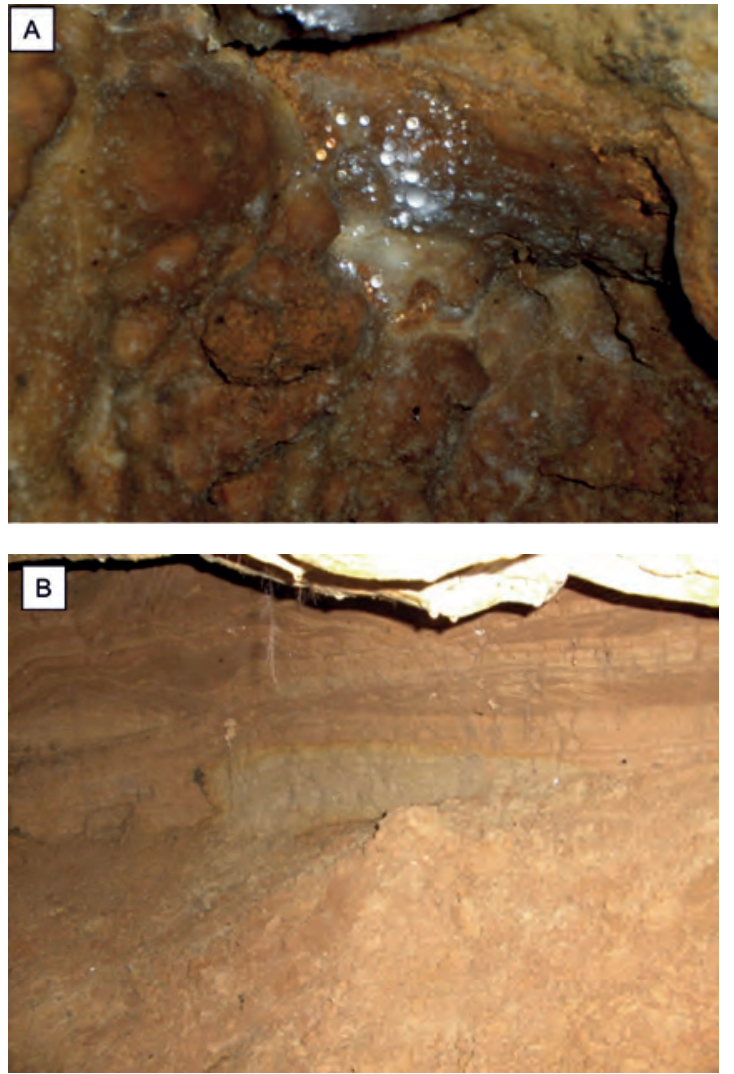


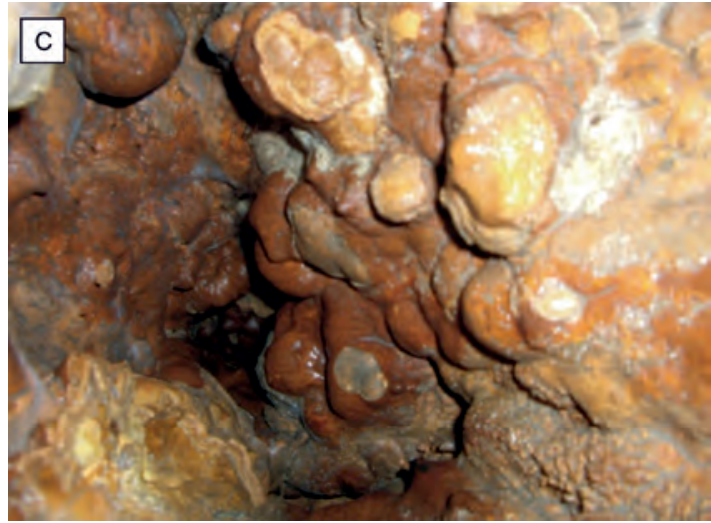

Fot. 8. Jaskinia Mała - wnętrze (fot. K. Jóźwiak, 2007)

Photo 8. Small Cave - interior (photo by K. Jóźwiak, 2007)

\section{Jaskinia Draba}

Znajduje się na północnym stoku wzgórza ok. 150 metrów w kierunku E od Jaskini Za Kratą. Powstała na szczelinach o kierunku NW-SE i NE-SW o wymiarach ok. $35 \mathrm{~m}$ długości i $4 \mathrm{~m}$ głębokości. Zachowały się tam bardzo drobne nacieki oraz fragmenty namulisk. Ze względów bezpieczeństwa jaskinia do niedawna była zasypana. Można było się do niej wczołgać otworem o wysokości ok. 0,4 m (Szynkiewicz 1977). Obecnie jaskinia nosi ślady oberwania się części mas skalnych i ma charakter zawaliskowy z dość niestabilnym wnętrzem (Jóźwiak 2007) - ryc. 9.

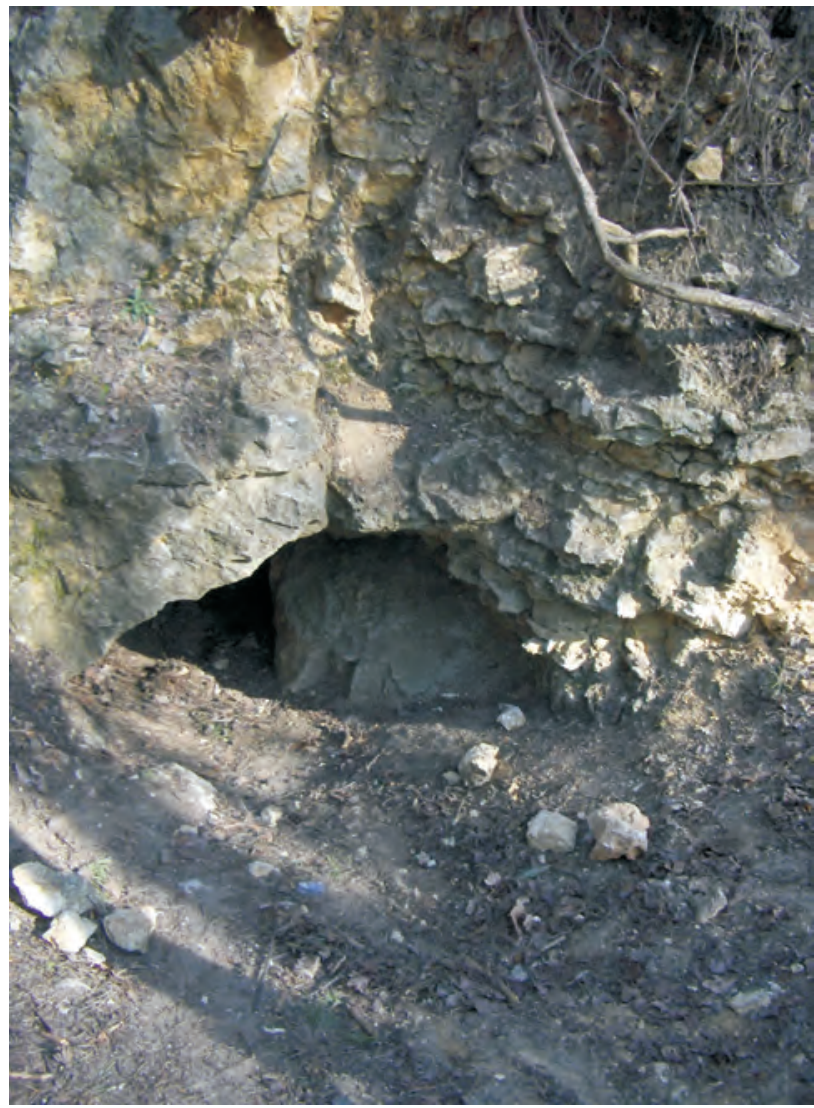

Fot. 9. Jaskinia Draba - wejście do jaskini (fot. K. Jóźwiak, 2007)

Photo 9. Draba Cave - entrance to the cave (photo by K. Jóźwiak, 2007)

\section{Podsumowanie i dyskusja}

Góra Zelce znajduje się w obrębie Załęczańskiego Parku Krajobrazowego (ZPK) utworzonego w 1978 roku, którego głównym celem była ochrona jurajskiego krajobrazu Wyżyny Wieluńskiej. Co istotne, Góra Zelce została objęta ochroną rezerwatową już w 1971 roku. Oprócz poszczególnych obszarów objętych ochroną rezerwatową, główną oś stanowi Działoszyński Przełom Warty o długości około $20 \mathrm{~km}$. Jest on bardzo charakterystyczną formą terenu, wyraźnie rzucającą się w oczy na opracowaniach kartograficznych (ryc. 1A, ryc. 1B). Uwidacznia się ona w formie łuku, gdzie rzeka Warta płynie w kierunku wschodnim, przeciskając się przez przełom rzeczny i dalej zawracając w kierunku północno-wschodnim. Jak wspomniano wcześniej sam ZPK, pomimo położenia w obrębie Wyżyn Polskich, poza nielicznymi miejscami, nie posiada wybitnie wyżynnego charakteru.

Opisywana góra przez wiele dziesięcioleci była miejscem intensywnych prac górniczych, których ślady do dziś są dobrze widoczne w terenie. W strefie szczytowej wzniesienia występują ślady licznych małych wyrobisk (ryc. 4, fot. 10), zaś w zboczach wiele mniejszych i większych kamieniołomów. Stoki doliny Warty aż po stoki Góry Zelce porozcinane są licznymi parowami. Od strony geomorfologicznej należy uznać, że badany obszar jest silnie przekształcony antropogenicznie.

Głównym celem powołania Rezerwatu „Węże” na Górze Zelce była ochrona wapiennego ostańca jurajskiego (przyroda nieożywiona) oraz muraw kserotermicznych (przyroda ożywiona). Analizując stan środowiska na opisywanym obszarze należy zastanowić się nad zakresem ochrony rezerwatowej. Należy pamiętać, iż w dużej części powierzchnia ostańca krasowego nie jest powierzchnią naturalną (fot. 10). Cały czas widoczne są ślady prac górniczych, takie jak wyrobiska i małe hałdy (ryc. 4). W przestrzeni leśnej istnieją pozostałości po szeregu ścieżek, które stanowiły miejsca silnej erozji wąwozowej. Sam system jaskiniowy posiada już niewiele fragmentów szaty naciekowej, która raczej jest trudna do dalszej antropogenicznej degradacji. Należy podkreślić, że to co było względnie łatwe do wydobycia zostało już zabrane podczas prac górniczych, reszta zaś przez niepoprawnych turystów lub poszukiwaczy minerałów (kalcytu i form naciekowych). Zdaniem autorów, jeśli udałoby się poprawić bezpieczeństwo zwiedzania jaskiń (odnowić zabezpieczenia), obiekty te jak dawniej powinny być dostępne dla powszechnej turystyki i edukacji.

\section{Literatura}

Baraniecka, M.D., Sarnacka, Z., 1971. Stratygrafia czwartorzędu i paleogeografia dorzecza Widawki. Biuletyn Instytutu Geologicznego 254, 157-240.

Bezkowska, G., Kamiński, J., Kobojek, S., Majchrowska, A., Wiluś, R., Załoba, M., 1999. Dolina Warty - przyroda i człowiek, [w:] Nauki geograficzne a edukacja społeczna. Materiały XLVIII Zjazdu PTG, Łódź, 9-11.09.1999 r.

Cyrek, K., 1996. Osadnictwo schyłkowopaleolityczne w Zakolu Załęczańskim doliny Warty. Biblioteka Muzeum Archeologicznego i Etnograficznego w Łodzi 30, 1-194.

Czyżewska, K., Olaczek, R. (red.), 1992. Załęczański Park Krajobrazowy. Przewodnik. Wydawnictwo ARW, PROART, Sieradz. 


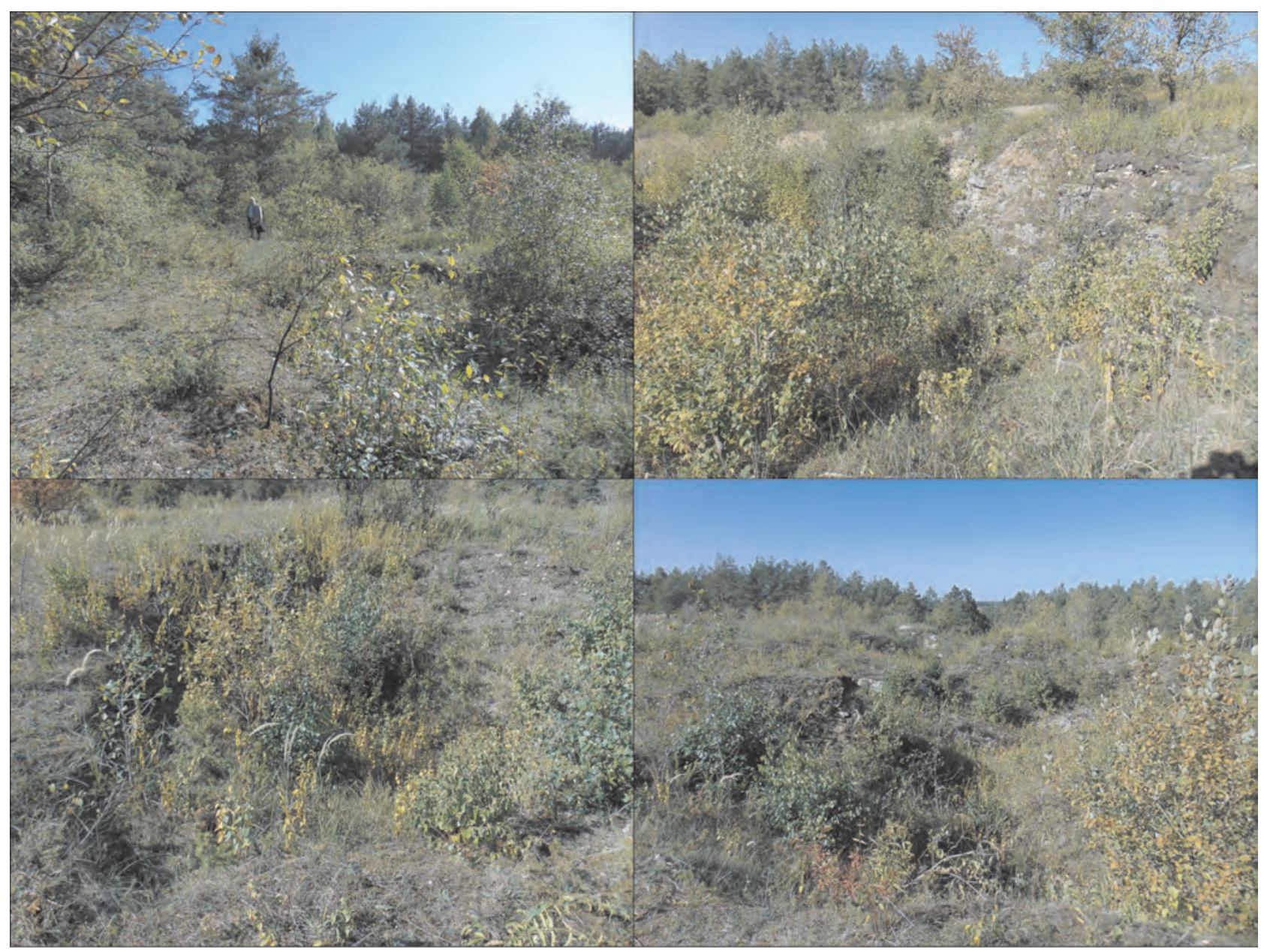

Fot. 10. Ślady po działalności górniczej na Górze Zelce (fot. A. Szmidt, 2019)

Photo 10. Traces of mining activity on Mount Zelka (photo by A. Szmidt, 2019)

Dylikowa, A., 1973. Geografia Polski. Krainy geograficzne. PZWS, 1-816. Dynowska, I., 1983. Źródła Wyżyny Krakowsko-Wieluńskiej i Miechowskiej. Studia Ośrodka Dokumentacji Fizjograficznej 11.

Głazek, J., Sulimski, A., Szynkiewicz, A., Wysoczański-Minkowicz, T., 1977. Kopalny kras ze środkowoplejstoceńskimi kręgowcami w Drabach koło Działoszyna, Prace Uniwersytetu Śląskiego 185, Kras i Speleologia $1(10), 42-58$.

Haisig, J., Wilanowski, J., Biernat, S., Kaziuk, H., Kotlicki, S., 1979. Mapa geologiczna Polski w skali 1:200 000 ark. Kluczbork, wyd. B, Mapa geologiczna odkryta, bez utworów czwartorzędowych. Państwowy Instytut Geologiczny, Warszawa.

Hałka, Ł., 2009. Formy krasu reprodukowanego w okolicy Węży koło Działoszyna. Materiały 43. Sympozjum Speleologicznego, Sekcja Speleologiczna Polskiego Towarzystwa Przyrodników im. M. Kopernika, Zamość, 54-55.

Jaksa, A., Szmidt, A., 2008. Wpływ tektoniki dysjunktywnej na rozmieszczenie kemów na obszarze województwa łódzkiego w świetle analizy kartograficznej, [w:] Florek, W., Kaczmarzyk, J., Współczesne problemy geomorfologii. Landform Analysis 9, 146-150.

Jaskulski, M., Szmidt, A., 2015. Rzeźba terenu Lasu Łagiewnickiego w Łodzi jako atrakcja turystyczna. Turyzm 25 (2), 27-35.

Jóźwiak, K., 2007. Fizycznogeograficzna charakterystyka okolic wsi Węże w Załęczańskim Parku Krajobrazowym - jaskinie rezerwatu Węże. Licencjat, Katedra Geografii Fizycznej WNG, Uniwersytet Łódzki, $1-40$.

Klajnert, Z., 1978. Zanik lodowca warciańskiego na Wysoczyźnie Skierniewickiej i jej północnym przedpolu. Acta Geographica Lodziensia 38, 1-149.
Klatkowa, H., 1972. Paleogeografia Wyżyny Łódzkiej i obszarów sąsiednich podczas zlodowacenia warciańskiego. Acta Geographica Lodziensia 28, 1-220.

Klimek, K., 1966. Deglacjacja północnej części Wyżyny Śląsko-Krakowskiej w okresie zlodowacenia środkowopolskiego. Prace Instytutu Geografii PAN 53, Kraków, 1-136.

Krysiak, S., Majchrowska, A., 2001. Funkcje turystyczno-rekreacyjne parków krajobrazowych, [w:] Bezkowska, G. (red.), Przewodnik sesji terenowych konferencji „Park krajobrazowy - i co dalej?”, Załęcze Wielkie, Uniwersytet Łódzki, Zakład Gleboznawstwa i Geoekologii, 32-47.

Krysiak, S., Papińska, E., 2005. Konflikty człowiek - środowisko w Załęczańskim Parku Krajobrazowym, [w:] Hibszer, A., Partyka, J. (red.), Między ochroną przyrody a gospodarką - bliżej ochrony. Konflikty człowiek-przyroda na obszarach prawnie chronionych w Polsce. Polskie Towarzystwo Geograficzne, Oddział Katowicki, Ojcowski Park Narodowy, Sosnowiec-Ojców, 180-189.

Krzemiński, T., 1965. Przełom doliny Warty przez Wyżynę Wieluńską. Acta Geographica Lodziensia 21, 1-95.

Krzemiński, T., 1974. Geneza młodoplejstoceńskiej rzeźby glacjalnej w dorzeczu środkowej Warty. Acta Geographica Lodziensia 36, 1-141.

Krzemiński, T., 1986. Paleogeograficzne tło rozwoju doliny Załęczańskiego Łuku Warty (Wyżyna Wieluńska). Acta Universitatis Lodziensis, Folia Sozologica 2, 149-178.

Laskowski, S., Papińska, E., Tołoczko, W., 2001. Różnorodność przyrodnicza Załęczańskiego Parku Krajobrazowego na przykładzie wybranych stanowisk. Problemy Ekologii Krajobrazu 9, 99-112. 
Lewandowski, J., 1982. Zasięg lądolodu zlodowacenia oerodkowopolskiego na Wyżynie Śląskiej. Biuletyn Instytutu Geologicznego 337 Z badań czwartorzędu w Polsce 26, 115-136.

Migoń, P., 2006. Geomorfologia. Wydawnictwo Naukowe PWN, Warszawa.

Nowak, W.A., 1993. Skrasowienie podziemne wapieni i jego odzwierciedlenie w rzeźbie Wyżyny Krakowsko-Wieluńskiej w rejonie Częstochowy. Studia Ośrodka Dokumentacji Fizjograficznej 21, 9-137.

Olaczek, R., Czyżewska, K., 1986. Załęczański Park Krajobrazowy, charakterystyka wartości, ich ochrona i wykorzystanie. Acta Universitatis Lodziensis, Folia Sozologica 2, 7-68.

Papińska, E., 2001a. Załęczański Park Krajobrazowy, [w:] Bezkowska, G. (red.), Przewodnik sesji terenowych konferencji „Park krajobrazowy - i co dalej?", Załęcze Wielkie, Uniwersytet Łódzki, Zakład Gleboznawstwa i Geoekologii, 6-15.

Papińska, E., 2001b. Walory poznawcze południowej części Załęczańskiego Parku Krajobrazowego, [w:] Bezkowska, G. (red.), Przewodnik sesji terenowych konferencji „Park krajobrazowy - i co dalej?”, Załęcze Wielkie, Uniwersytet Łódzki, Zakład Gleboznawstwa i Geoekologii, 16-31.

Papińska, E., Tołoczko, W., 2002. Walory abiotyczne Załęczańskiego Parku Krajobrazowego, [w:] Kurowski, J.K., Witosławski, P. (red.), Funkcjonowanie parków krajobrazowych w Polsce. Wydawnictwo Uniwersytetu Łódzkiego, 189-193.

Pożaryski, W., 1974. Tektonika, część 1: Niż Polski, [w:] Budowa geologiczna Polski, t. IV. Państwowy Instytut Geologiczny, Warszawa, 13-34 i 239-314.

Samsonowicz, J., 1934. Zjawiska krasowe i trzeciorzędowa brekcja kostna w Wężach pod Działoszynem. Zabytki Przyrody Nieożywionej. Wydawnictwo Państwowe Muzeum Archeologicznego, Warszawa 3, 151-162.

Solon, J., Borzyszkowski, J., Bidłasik, M., Richling, A., Badora, K., Balon, J., Brzezińska-Wójcik, T., Chabudziński, Ł., Dobrowolski, R., Grzegorczyk, I., Jodłowski, M., Kistowski, M., Kot, R., Krąż, P., Lechnio, J., Macias, A., Majchrowska, A., Malinowska, E., Migoń, P., Myga-Piątek, U. Nita, J., Papińska, E., Rodzik, J., Strzyż, M., Terpiłowski, S., Ziaja, W., 2018. Physico-geographical mesoregions of Poland: Verification and adjustment of boundaries on the basis of contemporary spatia data. Geographia Polonica 91 (2), 143-170 (Supplementary file).

Stupnicka, E., 1997. Geologia regionalna Polski. Wydawnictwa Geologiczne, Warszawa.
Szelerewicz, M., Górny, A., 1986. Jaskinie Wyżyny Krakowsko-Wieluńskiej. Wydawnictwo PTTK „Kraj”, Warszawa-Kraków.

Szmidt, A., 2006. Wpływ wychodni oraz podłoża mezozoicznego na rzeźbę i osady plejstocenu okolic Siedlątkowa. Materiały Konferencyjne XIII Konferencji „Stratygrafia Plejstocenu Polski” nt. Plejstocen południowej Warmii i zachodnich Mazur na tle struktur podłoża, Państwowy Instytut Geologiczny, 136-138.

Szubert, M., 2012. Plejstoceńska morfogeneza Wyżyny Woźnicko-Wieluńskiej związana ze stadiałem maksymalnym zlodowacenia Odry w świetle geostatystycznej rekonstrukcji powierzchni podplejstoceńskiej. Wydawnictwo Naukowe Uniwersytetu Pedagogicznego, Kraków, 1-181.

Szynkiewicz, A., 1971. Rozmieszczenie jaskiń na Górze Zelce koło Działoszyna. Speleologia 6(1-2), 49-57.

Szynkiewicz, A., 1977. Rezerwat przyrodniczo-geologiczny „Węże” na Górze Zelce koło Działoszyna nad Wartą. Acta Universitatis Lodziensis, Nauki matematyczno-przyrodnicze, seria II, 5, 123-142.

Szynkiewicz, A., 2014. Jura Wieluńska, Wycieczki geologiczne, Wieluń. Gmina Wieluń, 1-69.

Szynkiewicz, A., Wierzbowski, A., Nadachowski, A., Stefaniak, K., Kicińska, D., Marciszak, A., Ratajczak, U., Trusiński, D., Dobroc, A., Gajda, K., Perliceusz, T., Trusińska, K., 2015. Góra Zelce. Materiały 49. Sympozjum Speleologicznego, Załęcze Wielkie 22-25.10.2015, Sesja terenowa B, 14-42.

Tołoczko, W., Szmidt, A., 2018. Rędziny rezerwatu „Węże” w Załęczańskim Parku Krajobrazowym. Acta Universitatis Lodziensis, Folia Geographica Physica 17, 51-60.

Turkowska, K., 2006a. Geomorfologia regionu łódzkiego, Wydawnictwo Uniwersytetu Łódzkiego, Łódź, 1-238.

Turkowska, K., 2006b. Mapa geomorfologiczna regionu łódzkiego, [w:] Turkowska, K., Geomorfologia regionu łódzkiego. Łódź.

Turkowska, K., Szmidt, A., 2014. Próba cyfrowej adaptacji Mapy geomorfologicznej regionu Łódzkiego. X Zjazd Geomorfologów Polski nt. „Krajobrazy młodoglacjalne - ich morfogeneza, teraźniejszość, przyszłość". Toruń, 16-19 września 2014. Stowarzyszenie Geomorfologów Polskich, Wydział Nauk o Ziemi, Uniwersytet Mikołaja Kopernika w Toruniu.

Zadworny, Z., 1974. Łuk Warty z rezerwatem Węże. Przyroda Polska 3, 28-29.

Zadworny, Z., 1977. Zjawiska krasowe Łuku Warty. Wszechświat 9, 229231. 